\title{
Students' Perception of Mystical and Pathogenic Agents of Disease Causation in Enugu State Nigeria
}

\author{
Emmanuel C. Anizoba, Innocent Ebere Okereke \& \\ Geoffrey Chiazo Nganwuchu \\ http://dx.doi./org/10.4314/ujah.v21i1.9
}

\begin{abstract}
The study investigated students' perception of mystical and pathogenic agents of disease causation. Guided by four research questions and two null hypotheses, the study employed a descriptive survey research design. It was carried out in Obollo-Afor Education Zone of Enugu State of Nigeria. A sample of 370 SS2 Biology students was drawn from the population $(4,828)$ using a proportionate stratified random sampling technique. The instrument for data collection was a questionnaire in Likert format whose reliability coefficient was 0.84 , determined using Cronbach Alpha. Mean and standard deviation was used to answer the research questions while t-test was used to test the null hypotheses at 0.05 level of significance. Results revealed that students were aware that pathogenic agents such as virus, bacteria, pathogenic fungi, protozoa and some worms cause diseases to man. They had the awareness that some diseases are associated with mystical agents such as oathbreaking, and witches among others. Also, students' school location had no significant influence on their mean perception scores of the mystical and pathogenic agents of disease causation. These enable students to have a broader knowledge of disease causations and being able to avoid such causes in order to build a healthy sustainable future. Recommendations and conclusion were made.
\end{abstract}

Keywords: Students, Biology, Diseases, Mystical Agents, and Pathogenic Agents 


\section{Introduction}

Biology is a life science that is interested in the study of the structures and functions of living organisms. It is the branch of science that studies living things (Ramalingam, 2005). These living things studied by Biologists are plants and animals. Okereke and Nzewi (2018) defined Biology as the study of living things and their relationships both at macroscopic and microscopic levels. Living things can either be macroscopic such that they are seen without magnification and/or microscopic if they are seen with aided eye. Among the branches of Biology is Microbiology, this branch of Biology focuses on the study of microscopic organisms and how they interact with other living organisms. Microorganisms have beneficial effects in nature, medicine and industry. On the other hand, microorganisms have harmful effects and as such, cause different diseases. Disease-causing microorganisms are said to be pathogenic and specifically are called pathogens. The need for students to be aware of microorganisms around us and their actions made it possible for Biology students to be exposed to the harmful effects of microorganisms in their senior secondary one (SS1) Biology class (National Educational Research and Development Council [NERDC], 2008). Students in learning the topic; harmful effects of microorganisms are introduced to some diseases caused by pathogenic microorganisms.

A disease is a deviation from the normal state of health in which signs and symptoms are shown. It is a condition that is diagnosed by a physician or other medical expert (Wikman, Marklund \& Alexanderson, 2005). It is also an abnormal condition that affects living organisms. For the purpose of this article, a disease is defined as a disordered state in health caused by varied factors and/or agents; which results in abnormal feeling. These factors and/or agents causing diseases can be said to be biological 
among which are pathogens, auto-immune disorder and genetics. It could also be environmental among which are culture and poor nutrition. Diseases when occur, and proper medication not given, can be debilitating and may result in death. As a result, people when sick, resort to either traditional medical treatment or western medical treatment and/or both to be healthy again. Since in Igbo communities, some cultural agents or beliefs capable of causing diseases may lack scientific proof, they are commonly referred to as mystical agents of disease causation. This article explored students' perception of mystical and pathogenic agents of disease causation.

\section{Mystical Agents of Disease Causation}

Mystical agents of diseases causation are those agents that are culturally believed to cause diseases to human beings which though, may lack scientific proof. For instance, it is believed in Igbo communities that there are some mystic forces in the universe which can be tapped and utilized to bring about some effects that can be good or bad (Omoregbe 1999). Some people have gotten access to these forces (supernatural powers) and make use of them as Omoregbe further explained. For example, people like the priest-physicians utilize the powers for good purposes such as in healing and solving difficult problems. Some other people, however, use these powers for evil purposes such as causing harms and mysterious diseases to others they termed enemies. These people that use the mystic forces wrongly maybe witches and sorcerers and they cause a lot of havoc. Some of the mystical diseases are madness (árá), stroke (mba mmuo), cracking headache with swollen face (okịị mgbawa isi) distended stomach (nju afo) and swollen-rotten leg ( $u k w u$ ure/asa ere) among others. Some of the mystical diseases when occur in an individual, such victim may 
be medically diagnosed okay but the victim will be dying internally. In this regard, African Traditional belief of the causes of some diseases is attributed to some mystical agents such as gods, ogbanje/repeater spirit, sorcerers, ancestral causes, fear, witches and wizards, swearing a false oath, blood-covenant breaking, breaking ancestral taboos, spiritual forces and their likes. Some of the mystical agents are shown in the appendix. Subsequently, some of the above-named mystical agents are explained.

\section{Witches and Sorcerers as Mystical Agents of Disease Causation}

Witchcraft and sorcery have been defined by different scholars. Idowu (1973) defined witchcrafts and Sorcery as attempts on the part of man to trap and control the supernatural resources of the universe for his benefit. Ekwunife (2011) buttressed on that definition that witchcraft and sorcery are man's efforts to manipulate and control natural and supernatural realities through incantations, spells, gestures and other learned techniques in order to produce surprising results for his selfish benefits. From the later definition, one becomes aware of the various techniques through which witches and sorcerers operate. Explaining further on the techniques of witchcraft and sorcery, Mbiti (1969:200) confirmed that sorcery involves the use of poisonous ingredients that are put into the food or drink of someone. These poisonous substances result in diseases in the victim. Further, Olupona (2004) observed that spell-casting and witchcraft are also ways one could become sick. Olupona maintained that people with evil powers could cause other people they see as their enemies or that is disrespectful to them to become sick as a way of punishment. As a result, many traditional African communities have the belief that certain illnesses which defy scientific treatment are brought about by witchcraft and unforeseen forces. 


\section{Fear as Mystical Agent of Disease Causation}

Fear can sometimes be debilitating. It is said to be debilitating when it torments our emotional wellbeing (Okereke \& Nzewi, 2018). However, Madu (1999) observed that fear is a spirit-force. It kills as fast as a bullet. It sets in motion, series of problems in the lives of men hence, debilitating or violent. When fear is violent, it aimed at diminishing the person's life-force. Madu opined that fear-inflicted victims experience symptoms among which are heavy pounding of heart without cause, breathing heavily and rapidly, tightness at pressure points, hypertension, traits of inferiority and insecurity, and withdrawing attitude from the crowd. A person who experiences the aforementioned symptoms is disordered and cannot be said to be healthy.

\section{Ogbanje/Repeater Spirit as a Mystical Agent of Disease Causation}

Ogbanje (repeater) is understood as a wicked spirit being that cause premature death in victims afflicted by it. Metuh (1970) observed that in Igbo society in most cases, they come as first born to their parents and they keep dying and coming back to the same parents, thus destroying their chances of having more than one child. This they do with deliberation to torment their parents, inflicts them with consistent miscarriages, and disease attached to it. In other words, some persistent miscarriages and infertilities are caused by a repeater (ogbanje).

\section{Breaking of Taboos and False Oath-taking as Mystical Agents of Disease Causation}

Taboos are things that have cultural prohibitions which attract grievous and mysterious punishments such as diseases when 
broken by any person. False oath-taking, on the other hand, is an act of swearing false oath on a crime committed by an individual using named substances in the presence of people or a deity. Many traditional healers and practitioners believe that disobeying taboos is one of the ways people could become sick (Gyekye, 1995). Taboos form an important part of African traditional belief. They are things, or a way of life, that is forbidden by a community or a group of people (Isiramen, 1998). Taboos are also a social or religious custom prohibiting or restricting a particular practice or forbidding association with a particular person, place or thing (Westerlund, 2006). Taboos being culturally forbidden things is beneficial. This is because taboos and oath-taking help to checkmate the excesses of human beings in various communities in Igbo land.

In using oath-taking as an instrument of securing life and property in African traditional belief, Ugwu (2007) recognized the involvement of two characters; one taking the oath and the deity who acts as both witness and executor of the terms of the oath; as well as justifies the truth or punishes the one telling lies. Ugwu further opined that the gods are believed to be in the position to punish or testify because they are regarded as impartial judges that punishes the person that take a false oath by inflicting the individual concerned with some mysterious sicknesses and diseases such as madness (árá), stroke (mba mmuo), cracking headache with a swollen face (okịi mgbawa isi) distended stomach (nju afọ) and swollen-rotten leg ( ukwu ure/asa ere) among others.

\section{Ancestral Cause as Mystical Agent of Disease Causation}

Good health traditionally could be understood in terms of the relationship one has with his/her ancestors. Iroegbu (2005) maintained that good health is believed to be as a result of 
appropriate behaviour exhibited by an individual. That is, living in accordance with the values and norms of the community where one belongs. Given the above, there are several ways traditional Africans explain or understand the causes of disease. For instance, a disease is often caused by attacks from evil or bad spirits. Some also believe that when the ancestors are not treated well, they could punish people with diseases (Magesa, 1997; Westerlund, 2006). Thus, Nyamiti (1984) rightly pointed out that when ancestors are neglected or forgotten by their relatives they are said to be angry with them and send them misfortunes as punishment. Their anger is usually appeased through prayers and rituals in the form of food and drinks. Based on the foregoing, some Igbo parents believe that some diseases are mystical and as such explain the same to their children. The existence of the mystical agents of disease causation, however, enables some parents especially the ardent traditionalists to believe that diseases can also be caused by other agents such as pathogens that are believed to have scientific proofs and can be medically diagnosed.

\section{Pathogenic Agents of Disease Causation}

Pathogens are disease-causing microorganisms. Among the pathogenic microorganisms are viruses, bacteria, fungi, and protozoa. Some worms such as hookworms, tapeworms, and other parasites are known to also cause diseases to man (Nordqvist, 2018). Over the years, there are widely known viral, bacterial, fungal and protozoal diseases that can be medically diagnosed and scientifically proven. For instance, common viral diseases are catarrh (common cold disease), measles, small pox, chicken pox, poliomyelitis, infectious hepatitis, human immune deficiency syndrome (AIDS) among others (Nweze, 2004). Bacterial diseases as exemplified by Junge (2011) include tetanus (Clostridium 
tetani), tuberculosis (Mycobacterium tuberculosis), typhoid (Salmonella typhi), cholera (Vibrio cholera), dysentery (Spirillum volutrans), syphilis (Treponema pallidum), gonorrhea (Neisseria gonorrhoeae) and bacterial meningitis (Neisseria meningitides). Also, while gastroenteritis (Entamoeba histolytica, giardia lamblia), malaria (plasmodium maleriae), and vaginitis (Trichomonas vaginalis) among others are protozoal diseases as Junge further stated, ring worm, oral thrush, vulvo-vaginalis, candidiasis among others are fungal diseases (Nweze, 2004). Schistosomiasis, blastocystosis, amoebiasis among others are caused by worms (Nordqvist, 2018). Diseases which result to disorderliness in the body systems of their victims can be brought about and/or worsen by different factors.

For instance, genetics is among these factors. Some diseases that are attributed to genetics and such diseases can be inherited by the successive offspring of the victims. Genetic diseases may not be cured but managed. For instance, when there are gene mutations, chromosomal abnormalities, rhesus incompatibilities, blood genotype incompatibilities among others, some diseases develop which may not be cured. Some of the diseases are sickle cell anemia, down syndrome, miscarriages, high blood pressure, heart diseases, diabetes and cancer (Stöpple, n.d). Injuries such as cuts in the skin by unsterilized sharpened objects, and open wounds can be factors that can cause diseases. Further, poor nutrition, dirty environment (poor sanitation), taking unhygienic substances during cultural practices, abuse of substances and problems experienced during pregnancy and/or birth (congenital problems) are other factors that can result to diseases in man. As a result, diseases could be said to be multifactorial. Students' perception of disease causation may be influenced by the location of their schools. 
School location is an area where a school is precisely situated. A school may be situated in rural area or urban area. The location of a school may influence students' learning and the way they perceive or become aware of things in Biology. This influence of school location on students' learning may be initiated by the urban or rural characteristics of such a school. For instance, schools sited in urban areas are characterized by having electricity, adequate teachers, portable water, more learning facilities and infrastructures (Olutola, 2017). Conversely, school facilities and infrastructures may not be adequate in schools located in the rural areas and these appear to influence performance as well as perception of students. Onah (2011) noted that students in urban areas achieved more than students in the rural areas in science subjects. Besides, Olutola (2017) found out that students from urban schools performed better than students from rural schools in West African Senior School Certificate Examination (WASSCE) multiple-choice Biology test. This study, therefore, explores students' perception of mystical and pathogenic agents of disease causation.

\section{Statement of Problem}

Diseases are said to be multifactorial. This means that they can be caused by a number of factors which may be biological, personal and environmental. The pathogens and other parasites are among the factors that are biological and as a result, have scientific proof and can be medically diagnosed. Witches, sorcerers, repeater spirit, ancestral cause, oath-breaking among others that are believed to cause diseases to man are among the environmental factors that are culturally based. Some culturally-based environmental factors believed to cause diseases to man lack scientific proof, and may not be medically diagnosed. Such culturally-based environmental 
factors believed to cause diseases but lack scientific proof, and may not be medically diagnosed are referred to as mystical agents of disease causation. Are students aware of the pathogenic agents of disease causation? Are they also aware of the mystical agents of disease causation? Is students' awareness of mystical and pathogenic agents of disease causation influenced by their school location? This study, therefore, focuses on students' perception of mystical and pathogenic agents of disease causation.

\section{Purpose of the Study}

The purposes of the study in specific terms are to determine:

1. Students' perception of the mystical agents of disease causation.

2. Students' awareness of the pathogenic agents of disease causation.

3. If students' school location influences their perception of the mystical agents of disease causation.

4. If students' school location influences their perception of the pathogenic agents of disease causation.

\section{Research Questions}

1. What are the mean perception scores of Biology students on the mystical agents of disease causation?

2. What are the mean perception scores of Biology students on the pathogenic agents of disease causation?

3. What is the influence of students' school location on their mean perception scores of the mystical agents of disease causation? 
4. What is the influence of students' school location on their mean perception scores of the pathogenic agents of disease causation?

\section{Hypotheses}

The study was guided by the following hypotheses tested at 0.05 level of significance.

HO1 There is no significant influence of students' school location on their mean perception scores of the mystical agents of disease causation

$\mathrm{HO}_{2}$ There is no significant influence of students' school location on their mean perception scores of the pathogenic agents of disease causation?

\section{Theoretical Explanations}

Theoretically, the study hinges on three theories. Firstly, on the demonic theory of disease causation described by Feezer (1921). According to this theory, disease was caused by demons, one or more evil spirits that had fixed their abode in the victim's body. For this theory, the sick man was possessed of a devil. It maintained that it was logical to attempt to cure such a person by a system of incantation and sorcery which are things calculated to drive out the demon. In this case, the priest or man of religion was usually the medicine man or doctor whose good offices were required for eliminating the evil spirits of disease.

Secondly, on the germ theory of diseases causation which Waller (2004) wrote that its statement has special reference to the works of Louis Pasteur in the 1860s and then Robert Koch in the following decades that opened the door to research into the identification of disease-causing germs and potential life-saving treatments. For this theory, many diseases are caused by the 
presence and actions of specific micro-organisms within the body (bacteria). In other words, diseases are caused by germs which are disease-causing microorganisms (pathogens) and/or other parasites. Nutton (1983) added that even where a pathogen is the principal cause of a disease, environmental and hereditary factors often influence the severity of the disease and whether a potential host individual becomes infected when exposed to the pathogen. The germ theory facilitated the strategy for diagnosing and administering proper treatment of diseases. This theory is not just a lay man's discovery that lacks scientific backing; rather it has valid and authentic scientific accreditation.

Finally, on self-perception theory. Self-perception theory was developed by Daryl Bem in the late 1960's and early 1970's. The theory illustrates that "we are what we do." According to this theory, we interpret our own actions the way we interpret others' actions, and our actions are often socially influenced and not produced out of our own free will, as we might expect. Since our actions as pointed out in this theory, are often socially influenced and not produced out of our own free will, as we might expect, it goes a long way to explain that students' perception of the mystical agents of diseases causation may be socially influenced from the culture of the community where they found themselves.

\section{Method}

The design of the study was descriptive survey research design. The design was considered appropriate because it aims at describing in a systematic manner data collected on the facts about a given population (Nworgu, 2015). The study was conducted in Obollo-Afor Education zone of Enugu State of Nigeria. The zone is made up of three Local Government Areas that include Udenu, Igbo-Eze South and Igbo-Eze North Local Government Areas. It 
has 48 public secondary schools 16 of which are in Udenu, 10 in Igbo-Eze South and 22 Secondary Schools in Igbo-Eze North Local Government Areas. This area was chosen because it is made up of Igbo communities that cherish and uphold their customs and traditions.

The population of the study was all the 4,828 SS2 Biology students in the zone. The SS2 Biology students were used because they have been taught pathogenic microorganisms at their SS1 level and therefore have had foundational knowledge about pathogenic microorganisms (pathogens). The sample of the study was three hundred and seventy (370) SS2 Biology students. This number was computed using Taro Yamene's formula (Uniproject, 2016). The sample was drawn using proportionate stratified random sampling technique from the rural and urban areas of the three local government areas in the zone. One hundred and twentythree (123) SS2 Biology students were from Udenu Local Government Area, seventy-seven (77) SS2 Biology students were from Igbo-Eze South and one hundred and seventy (170) SS2 Biology students were from Igbo-Eze North Local Government Area; making the sample size of the study to be three hundred and seventy (370). Out of the 370 SS2 Biology students used for the study, one hundred and nighty (190) of them were from rural public secondary schools while the remaining one hundred and eighty (180) were from the urban public secondary schools.

The instrument used was a structured questionnaire on the mystical and pathogenic agents of disease causation developed by the researchers whose items were in Likert format of Strongly Agree (SA), Agree (A), Disagree (D) and Strongly Disagree (SD). In each of the items, the respondents were required to express their knowledge of diseases causation by ticking $(\sqrt{ })$ in any of the response options. In scoring the instrument, the 'SA' was assigned 
the score of 4, 'A' attracted the score of 3, 'D' was assigned a score of 2 while 'SD' was given a score of 1 . The Instrument was face validated by three experts from the University of Nigeria, Nsukka. One from the Department of Religion and Cultural Studies, another from the Department of Science Education and the third is a Measurement and Evaluation expert. The instrument was trial tested using 20 students in Igbo-Etiti Local Government Area which was an area different from the area where the study was carried out but shared common characteristics such as having the same academic calendar and curriculum. The trial tested instruments were scored and subjected to reliability measure using Cronbach Alpha for polychotomously scored items and a reliability index of 0.84 was obtained which according to Nworgu (2015) is appropriate for the study.

The instrument which contained items in two clusters of mystical and pathogenic agents was distributed to the sampled students from the three local government areas in the zone. The responded instruments were scored and analyzed quantitatively. The research questions were answered using mean and standard deviation while independent sample t-test was used to test the null hypotheses at 0.05 level of significance.

\section{Results}

Research Question 1: What are the mean perception scores of Biology students on the mystical agents of disease causation?

\section{Table 1: Mean Perception Scores of Biology Students on the Mystical Agents of Disease Causation}

Item Statement

Mean Std. Dev. Dec. 
I am aware that diseases are caused by mystical agents. $\quad 370$

$$
2.91 .992 \quad \text { Accept }
$$

Witches cause diseases.

\section{$2.76 \quad 968 \quad$ Accept}

Some diseases are caused by sorcerers.

$2.76 \quad 949 \quad$ Accept

Oath breaking results to diseases.

\section{$2.55 \quad 1.03 \quad$ Accept}

Some diseases are associated with ogbanje/repeater spirit. 370
$2.71 \quad 1.04$ Accept

Some diseases have ancestral causes.

$$
\begin{array}{lll}
2.86 & 921 \quad \text { Accept }
\end{array}
$$

Some diseases are associated with fear.

$$
2.51 \quad 1.067 \quad \text { Accept }
$$

Mean of Mystical Agents

\section{$2.72 \quad .583 \quad$ Accept

$$
\text { Accept }
$$

Overall Mean

Accept

\section{Acceptable Benchmark Mean Score $=\mathbf{2 . 5 0}$}

Table 1 above shows students' mean perception scores of the mystical agents of disease causation. The table indicated that Biology students' mean perception score on their awareness of the mystical agents of diseases causation was 2.91 with a standard deviation of .992. The mean score of 2.91 is higher than the acceptable benchmark mean score of 2.50. Also, Biology students' mean perception scores on the mystical agents of disease causation such as witches, sorcerers, oath breaking, ogbanje/repeater spirit, ancestral causes and fear were greater than the acceptable benchmark mean score of 2.50 as indicated in table 1 above. 
Research Question 2: What are the mean perception scores of Biology students on the pathogenic agents of disease causation?

Table 2: Mean Perception Scores of Students on the Pathogenic Agents of Disease Causation

Item Statement

Mean Std. Dev. Dec.

I am aware that diseases are caused by pathogens.

$\begin{array}{lll}3.48 & .707 & \text { Accept }\end{array}$

Viruses cause diseases.

$\begin{array}{llll}3.52 & .714 & \text { Accept }\end{array}$

Some diseases are caused by bacteria.

$$
3.48 \quad 663 \quad \text { Accept }
$$

Pathogenic fungi cause diseases.

$$
\begin{array}{lll}
3.40 \quad 680 & \text { Accept }
\end{array}
$$

Some diseases are caused by protozoa.

$$
\begin{array}{lll}
3.27 \quad 814 \quad \text { Accept }
\end{array}
$$

\section{$\begin{array}{lll}3.31 & .809 & \text { Accept }\end{array}$}

Mean of Pathogenic Agents

$$
\begin{array}{lll}
3.41 \quad 489 & \text { Accept }
\end{array}
$$

Overall Mean

$2.90 \quad 377 \quad$ Accept

\section{Acceptable Benchmark Mean Score $=\mathbf{2 . 5 0}$}

Table 2 above shows students' mean perception scores of the pathogenic agents of disease causation. The table revealed that Biology students' mean perception score on their awareness of the pathogenic agents of diseases causation was 3.48 with a standard deviation of .707. The mean score of 3.48 is greater than the acceptable benchmark mean score of 2.50. Also, Biology students' 
mean perception scores on the pathogenic agents of disease causation such as viruses, bacteria, pathogenic fungi, protozoa and worms were greater than the acceptable benchmark mean score of 2.50 as shown in the table 2 above.

Research Question 3: What is the influence of students' school location on their mean perception scores of the mystical agents of disease causation?

\section{Table 3: Influence of Students' School Location on their Mean perception scores of the Mystical Agents of Disease Causation}

\section{Item Statement}

\section{N Mean Std. Dev. Dec.}

Location

I am aware that diseases are caused by mystical agents. Urban $\begin{array}{llll}180 & 2.96 & 1.02 & \text { Accept }\end{array}$

$\begin{array}{llll}190 & 2.86 \quad 966 \quad \text { Accept }\end{array}$

Witches cause diseases.

Rural

$\begin{array}{llll}180 & 2.72 \quad .946 \quad \text { Accept }\end{array}$

$\begin{array}{llll}190 & 2.79 & .989 & \text { Accept }\end{array}$

Some diseases are caused by sorcerers.

$\begin{array}{llll}180 & 2.76 \quad .924 \quad \text { Accept }\end{array}$

$\begin{array}{llll}190 & 2.77 \quad 975 \quad \text { Accept }\end{array}$

Oath breaking results to diseases.

Urban

Rural

$\begin{array}{llll}180 & 2.57 & .981 & \text { Accept }\end{array}$

Urban

Urban

Rural

$\begin{array}{llll}190 & 2.54 & 1.08 & \text { Accept }\end{array}$

Rural 
Some diseases are associated with ogbanje/repeater spirit. Urban $\begin{array}{llll}180 & 2.67 & 1.07 & \text { Accept }\end{array}$

$$
\begin{array}{llll}
190 & 2.74 & 1.02 & \text { Accept }
\end{array}
$$

Some diseases have ancestral causes.

Rural

Urban

$\begin{array}{llll}180 & 2.86 & .934 & \text { Accept }\end{array}$

$\begin{array}{llll}190 & 2.87 & .911 & \text { Accept }\end{array}$

Some diseases are associated with fear.

$\begin{array}{llll}180 & 2.51 & 1.04 & \text { Accept }\end{array}$

$\begin{array}{llll}190 & 2.51 & 1.09 & \text { Accept }\end{array}$

Mean of Mystical Agents

$\begin{array}{llll}180 & 2.72 & .578 & \text { Accept }\end{array}$

$\begin{array}{llll}190 & 2.73 & .589 & \text { Accept }\end{array}$

\section{Acceptable Benchmark Mean Score $=\mathbf{2 . 5 0}$}

Table 3 above shows the influence of students' school location on their mean perception scores of the mystical agents of disease causation. The table revealed that Biology students in the urban area had a mean mystical perception score of 2.72 and a standard deviation of .578 while those in the rural area had a mean mystical perception score of 2.73 and a standard deviation of .589; with a mean score difference of 0.01 in favour of students in the rural area.

HO1: There is no significant influence of students' school location on their mean perception scores of the mystical agents of disease causation 
Table 4: t-test Analysis on the Mystical Agents of Disease Causation according to Students' Location

\begin{tabular}{|c|c|c|c|c|c|}
\hline & Location & $\mathrm{N}$ & Mean & Std. & Dev \\
\hline \multirow{4}{*}{$\begin{array}{l}\text { Mystical } \\
\text { Agents }\end{array}$} & $\mathrm{t}$ & $\mathrm{df}$ & \multicolumn{3}{|c|}{ Sig. (2-tailed) Urban } \\
\hline & 180 & 2.72 & \multirow{2}{*}{\multicolumn{2}{|c|}{.578}} & -.119 \\
\hline & 368 & .905 & & & \\
\hline & Rural & 190 & 2.73 & .589 & \\
\hline
\end{tabular}

Table 4 above shows that the influence of students' school location on their mean perception scores of the mystical agents of disease causation; which had a t-score of -.119 at 368 degree of freedom is not significant. The null hypothesis that there is no significant influence of students' school location on their mean perception scores of the mystical agents of disease causation is therefore not rejected.

Research Question 4: What is the influence of students' school location on their mean perception of the pathogenic agents of disease causation?

\section{Table 5: Influence of Students' School Location on their Mean perception scores of the Pathogenic Agents of Disease Causation}

Item Statement

Location

N Mean Std. Dev. Dec.

I am aware that diseases are caused by pathogens. Urban

$\begin{array}{llll}180 & 3.51 & .673 & \text { Accept }\end{array}$

$\begin{array}{llll}190 & 3.45 & .738 & \text { Accept }\end{array}$

Rural 
Viruses cause diseases.

Urban

$\begin{array}{llll}180 & 3.59 & .632 & \text { Accept }\end{array}$

$\begin{array}{llll}190 & 3.46 & .781 \quad \text { Accept }\end{array}$

Some diseases are caused by bacteria.

Rural

$\begin{array}{llll}180 & 3.47 & .647 & \text { Accept }\end{array}$

Urban

Rural

$\begin{array}{llll}190 & 3.48 \quad 680 & \text { Accept }\end{array}$

Pathogenic fungi cause diseases.

Urban

$\begin{array}{llll}180 & 3.36 & .682 & \text { Accept }\end{array}$

Rural

$\begin{array}{llll}190 & 3.44 & 677 & \text { Accept }\end{array}$

Some diseases are caused by protozoa.

Urban

$\begin{array}{llll}180 & 3.18 & .835 & \text { Accept }\end{array}$

Rural

$\begin{array}{llll}190 & 3.35 & .787 & \text { Accept }\end{array}$

Some worms cause diseases to man.

$\begin{array}{llll}180 & 3.31 & .828 & \text { Accept }\end{array}$

$\begin{array}{llll}190 & 3.32 & .794 & \text { Accept }\end{array}$

Mean of Pathogenic Agents

Urban

$\begin{array}{llll}180 & 3.40 & .479 & \text { Accept }\end{array}$

Rural

Urban

Rural

$\begin{array}{llll}190 & 3.42 & .499 & \text { Accept }\end{array}$

\section{Acceptable Benchmark Mean $=\mathbf{2 . 5 0}$}

Table 5 above shows the influence of students' school location on their mean perception scores of the pathogenic agents of disease causation. The table showed that Biology students in the urban area had a mean pathogenic perception score of 3.40 and a standard deviation of .479 while those in the rural area had a mean pathogenic perception score of 3.42 and a standard deviation of 
.499 ; with a mean score difference of 0.02 in favour of students in the rural area.

HO2: There is no significant influence of students' school location on their mean perception scores of the pathogenic agents of disease causation.

Table 6: t-test Analysis of the Pathogenic Agents of Disease Causation according to Students' Location

\begin{tabular}{|c|c|c|c|c|c|}
\hline & Location & $\mathrm{N}$ & Mean & Std. & Dev. \\
\hline & $\mathrm{t} \quad \mathrm{df}$ & Sig. & -tailed) & & \\
\hline & Urban & 180 & 3.40 & .479 & \\
\hline Pathogenic & $368 \quad .813$ & & & & \\
\hline Agents & Rural & 190 & 3.42 & .499 & \\
\hline
\end{tabular}

Table 6 above shows that the influence of students' school location on their mean perception scores of the pathogenic agents of disease causation which had a t-score of -.237 at 368 degree of freedom is not significant. Therefore, the null hypothesis that there is no significant influence of students' school location on their mean perception scores of the pathogenic agents of disease causation is not rejected.

\section{Discussion}

It was revealed in table 1 that the students' mean perception scores of the mystical agents were greater than the acceptable benchmark mean score of 2.50. These purport that students believe that some disease of man is attributed to some mystical agents such as witches, sorcerers, oath breaking, ogbanje/repeater spirit, ancestral 
causes and fear. This is in line with Olupona (2004) who observed that spell-casting and witchcraft are ways one could become sick. It also substantiates Gyekye (1995) who asserted that many traditional healers and practitioners believed that disobeying taboos is one of the ways people could become sick. Further, it is in line with Madu (1999) who opined that fear-inflicted victims experience symptoms among which are heavy pounding of heart without cause, breathing heavily and rapidly, tightness at pressure points, hypertension, traits of inferiority and insecurity, and withdrawing attitude from the crowd. Students' belief that mystical agents can cause diseases in spite of the fact that they are not scientifically proven might stem from their homes. For instance, some parents and elderly family members right from homes bring to the knowledge of their children about the mystical agents of disease causation and they grow with such knowledge. The knowledge of the mystical agents that can cause diseases might also be acquired by students through enculturation and peer influence. Students grow with such knowledge and bring the same to Biology classrooms during learning episodes.

It is shown in table 2 that Biology students were aware of the pathogenic agents of disease causation. Also, the students' mean perception scores on the pathogenic agents of disease causation such as viruses, bacteria, pathogenic fungi, protozoa and worms as revealed in table 2 were greater than the acceptable benchmark mean score of 2.50. The results indicated that students believed that diseases of man are caused by pathogenic agents. This is in line with Nordqvist (2018) that microorganisms such as viruses, bacteria, some fungi, protozoa and some worms such as hookworms, tapeworms, and other parasites are pathogenic because they are known to cause diseases to man. Students are taught in their Biology class that widely known diseases of man 
such as catarrh, measles, tuberculosis, syphilis, ring worm, malaria, and schistosomiasis among others are caused by pathogens and other parasites.

In table 3, it was revealed that Biology students in the urban area had a mean mystical perception score of 2.72 while those in the rural area had a mean mystical perception score of 2.73; with a mean score difference of 0.01 in favour of those in the rural area. Also, table 5 showed that Biology students in the urban area had a mean pathogenic perception score of 3.40 while those in the rural area had a mean pathogenic perception score of 3.42 ; with a mean score difference of 0.02 in favour of students in the rural area. However, further analyses in tables 4 and 6 showed no significant influence on students' school location on their mean perception scores of the mystical and pathogenic agents of disease causation. It, therefore, purports that students' school location, whether rural or urban, did not actually influence the way they perceive mystical and pathogenic agents of disease causation. The slight mean score difference noticed, may be attributed to the differences in the number of students (respondents) in both rural and urban areas.

However, students' awareness of the mystical agents of disease causation which they perhaps got from their homes and through enculturation, and bring same to Biology classrooms during the teaching/learning of the topic "Harmful effects of microorganisms", calls for introducing to them early; about the multifactorial nature of diseases. Through this knowledge, students would be well informed that although diseases are mostly caused by pathogens and parasites, there are many factors and practices whether cultural or not that can make individuals susceptible to diseases. Some of such factors and practices include genetic factors, open wounds/cuts in the skin by unsterilized sharpened 
objects, poor nutrition, dirty environment (poor sanitation), taking unhygienic substances during some cultural practices (like oathtaking), abuse of substances, taking foods that are preserved with carcinogenic substances, and problems experienced during pregnancy and/or birth (congenital problems). Students' knowledge of the multifactorial nature of diseases will foster authentic and well robust knowledge that can bring about effective awareness of diseases, their causes and prevention capable of promoting good health conditions of individuals and building of sustainable future.

\section{Contributions to Knowledge}

This study contributes that diseases are multifactorial and as such can be caused by a number of factors which can be biological and culturally-based. While teaching some topics in Biology lessons such as "microorganisms around us and their actions", teachers can use such topics in the curriculum to bring to the knowledge of the students about the multifactorial nature of diseases which will foster authentic and well robust learning. This no doubt is capable of enhancing the effective awareness of diseases, their causes and prevention which promote good health conditions of individuals and building of sustainable future.

\section{Recommendations}

Based on the findings and discussions, it is recommended as follows:

i. Biology teachers while teaching "the harmful effects of microorganisms" should expose their students to the multifactorial nature of diseases. 
ii. Students should be informed about how some cultural practices termed mystical agents such as taking unhygienic substances during oath-taking, unsanitary skin incisions (e.g. tattoos) with unsterilized equipment among others could make an individual susceptible to diseases.

iii. Parents as first "teachers" of their children should right from home, teach them about the pathogenic agents of disease causation and how some cultural agents otherwise known as mystical agents can make individuals susceptible to diseases.

iv. Curriculum planners should integrate "the multifactorial nature of diseases" into the school Biology curriculum for students to have broad knowledge about diseases, their causative agents and preventions.

\section{Conclusion}

The multifactorial nature of diseases explains that diseases in addition to being caused by pathogenic agents and parasites can also be triggered by other factors among which are cultural factors commonly called mystical agents. Students' perception of disease causation enables them to become abreast of the pathogenic agents and/or parasites that cause diseases to man, and have awareness of some cultural agents otherwise known as mystical agents that can make individuals susceptible to diseases. Biology teachers in conclusion, while teaching "Harmful Effects of Microorganisms" should also discuss the multifactorial nature of diseases to enable students to have broad knowledge about diseases, factors that can trigger them, and prevention of diseases which will enhance the building of sustainable future.

\section{Emmanuel C. Anizoba}

Department of Religion \& Cultural Studies 
University of Nigeria, Nsukka emmanuel.anizoba@unn.edu.ng

\section{Innocent Ebere Okereke}

Department of Science Education,

University of Nigeria, Nsukka innocent.okereke@unn.edu.ng

Nganwuchu, Geoffrey Chiazo

Department of Religion \& Cultural Studies

University of Nigeria, Nsukka geoffrey.nganwuchu@unn.edu.ng

\section{References}

Bem, D. (1960). Self-Perception Theory. Retrieved on $18^{\text {th }}$ February, 2019 from https://www.learningtheories.com/self-perception-theory-bem.html

Ekwunife A.N.O. (2011) Ripples in Roman Catholic Diocese of Awka, Anambra-State Nigeria Enugu: Snapp Press Ltd.

Feezer, L.W. (1921). Theories Concerning the Causation of Disease. Retrieved on 17th February, 2019 from https://ajph.aphapublications.org/doi/pdf/10.2105/AJPH.11. 10.908

Gyekye, K. (1995). African Philosophical Thought: The Akan Conceptual Scheme (rev. ed.). Philadelphia, PA: Temple University press.

Idowu, E. Bolaji (1973). African Traditional Religion: A Definition. London: S. C. M. Press

Iroegbu, P. (2005). 'Healing insanity: skills and expert knowledge of Igbo healers'. African Development, 30(3), 78-92. http://dx.doi.org/10.4314/ad.v30i3.22231 
Isiramen, C. (1998). Philosophy of Religion, Ethics and Early Church Controversies. Lagos: Associate Publishers.

Junge, T. (2011). Microbiology Review: Pathogens and Diseases. Retrieved on $14^{\text {th }} \quad$ February, 2019 from www.ast.org/pdf/326.pdf

Madu J.E. (1999) Honest to African Cultural Heritage, Calabar: Franedoh Publishers (Nig) Ltd.

Magesia, L. (1997), African Religion: The Moral Traditional of Abundant Life. New York: Orbis Books.

Mbiti, J.S (1969) African Religions and philosophy London: Heinemann Educational Books Ltd.

Metuh E.I. (1981) God and Man in African Religion. London: Cassell Ltd.

N.E.R.D.C. (2008). Senior Secondary School Curriculum-Biology. Abuja: NERDC Press.

Nordqvist, C. (2018). What's to know about parasites? Retrieved on 14th February, 2019 from https://www.medicalnewstoday.com/articles/220302.php

Nutton, V. (1983). The seeds of disease: an explanation of contagion and infection from the Greeks to the Renaissance. Medical History, 27(1), 1-34.

Nweze, C. (2004). Comprehensive Biology for Senior Secondary Schools. Surulere: A Johnson Publishers Ltd.

Nworgu, B.G. (2015). Educational Research Basic Issues and Methodology (3rd ed.). Nsukka: University Trust Publishers.

Nyamiti, C. (1984) Christ as Our Ancestor: Christology from an African Perspective. Lubaka: Press.

Okereke, I.E. \& Nzewi, U.M. (2018). Fear-inducing stimuli among students during Biology practical activities involving 
animal specimens. Journal of the Nigerian Academy of Education (JONAED), 14(2), 177-190.

Olupona, J.K. (2004) 'Owner of the day and regulator of the universe: Ifa Divination and healing among the Yoruba of South-Western Nigeria'. In: M. Winkelman \& P.M. Peeks (Eds.). Divination and Healing: Potent Vision. Tucson, AZ: University of Arizona Press.

Olutola, A.T. (2017). School location and gender as predictors of students' performance in wassce multiple choice test in biology. Liceo Journal of Higher Education Research, 117. doi: http://dx.doi.org/10.7828/ljher.v12i1.960

Omoregbe J.I. (1999) Comparative Religion Christianity and Other World Religions in Dialogue. Lagos: Joja Educational Research and publishers Ltd.

Onah, E.F. (2011). Influence of sex and school location on students' achievement in agricultural science. African Journal of Science, Technology and Mathematics Education (AJSTME), 1 (1) 96-102.

Ramalingam, S.T. (2005). Modern Biology for Senior Secondary Schools (3rd edition). Onitsha: Africana First Publishers Ltd.

Stöppler, M.C. (n.d). Genetic Diseases (Inherited) Symptoms, Causes, Treatments, and Prognosis. Retrieved on $14^{\text {th }}$ February, 2019 from https://www.medicinenet.com/genetic_disease/article.htm\# mitochondrial_genetic_inheritance

Ugwu, C.O.T. (2007). African Traditional Religion in the Security of Human Lives and Property in Journal of Religion \& Human Relations. Awka: Department of Religion \& Human Relationship Maiden Edition.

Waller, J. (2004). Discovery of the Germ. London: Icon Books. 
Westerlund, D. (2006) African Indigenous Religions and Disease Causation. Leiden: Brill NV.

Wikman, A., Marklund, S. \& Alexanderson, K. (2005). Illness, disease, and sickness absence: An empirical test of difference between concepts of ill health. Journal of Epidemiol Community Health, 59, 450-454

\section{Appendix}

\section{Images of some Mystical Agents that Cause Diseases to Man}

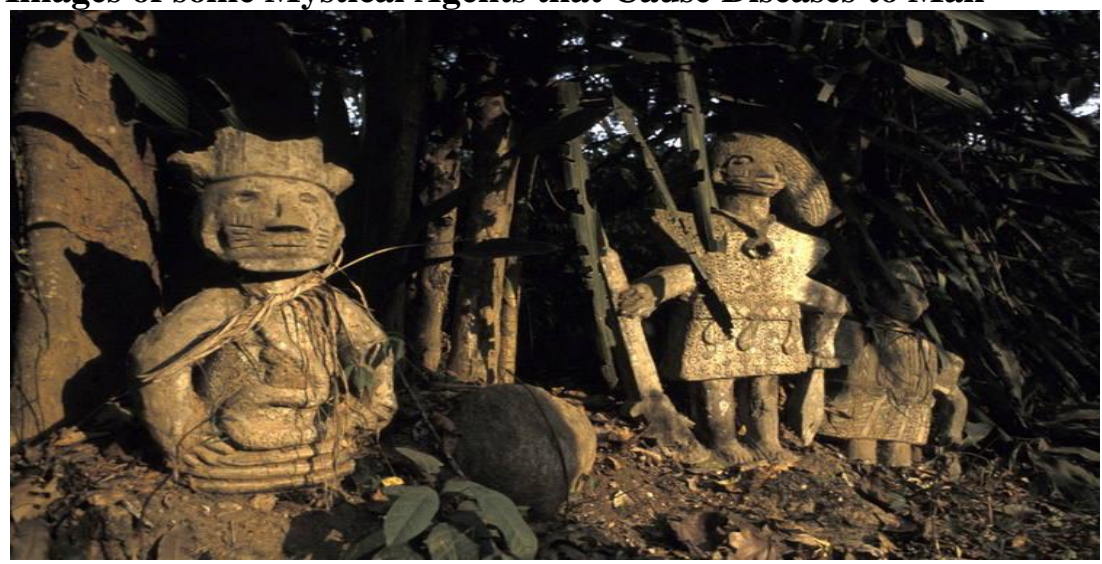

Symbols of African Traditional Ancestors that are believed to cause diseases to man

https://grandmarketsquare.com/wp-content/uploads/2018/11/The-LongJuJu-Shrine-of-Arochukwu.png 


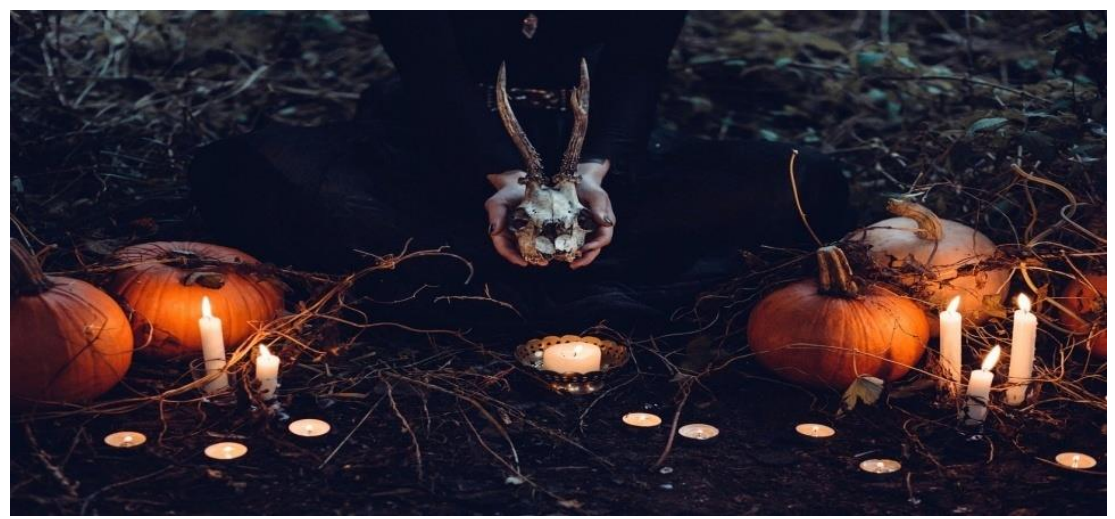

Symbols of African traditional Shrines where oath can be taken; which when false are believed to cause diseases to man (Source: S.L. Kreativez) https://i0.wp.com/www.slkreativez.com/wpcontent/uploads/2018/08/candle-1868640_1280.jpg?fit=1280\%2C853

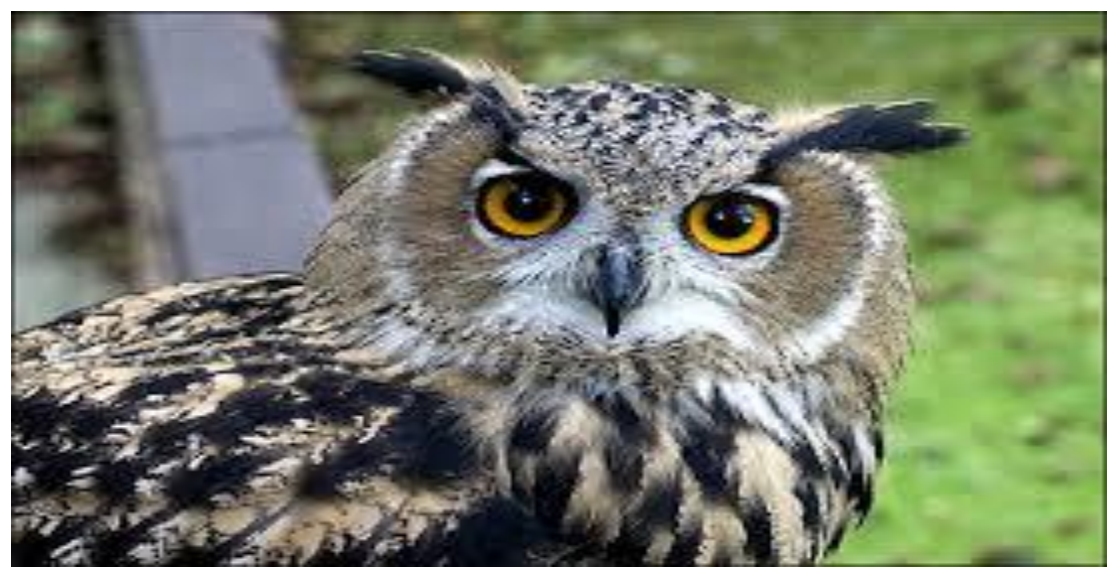

The Symbols of witches and wizards in African Traditional beliefs that cause diseases to man (Source: Yagbe Onilu) https://encryptedtbn0.gstatic.com/images?q=tbn:ANd9GcQB50VteMoZp30Ocb4V7Qnf WtCqWCUWdQrOfCsfIYNbC2dA5ZIiow 